\title{
Effect of Dietary Aloe vera and Yeast powder on muscle growth of broiler chicks
}

\author{
Pranab Doley $^{1^{*}}$, Ajit Singh $^{2^{*}}$, S. Gogoi ${ }^{3^{*}}$ and Neeraj ${ }^{4 *}$ \\ Department of Animal Nutrition \\ Sundereson School of Animal Husbandry \& Dairying SHIATS Allahabad,
}

\begin{abstract}
The purpose of this research work was to evaluate the Aloe vera (Aloe barbadensis) and Yeast (Saccharomyces Cerevisiae)powder. A total of 72 (Arbor-Acres) day old chicks were used in this study. Four levels of anAloe vera and Yeast powder at the rate of 0.00\%, 0.50\% (Yeast), 0.50\% (Aloe vera), and 0.50\% Yeast $+0.50 \%$ Aloe vera were incorporated into the basal diet for six weeks. Feeding period for all groups was lasted for 42 days. Results revealed a significant effect of Aloe vera and Yeast powder in feeds on weight of breast, thigh, and leg $(P<0.05)$ were significantly on feed supplemented with $0.50 \%$ Yeast $+0.50 \%$ Aloe vera powder. It was concluded from this study that $0.50 \%$ Yeast $+0.50 \%$ Aloe vera powder feed supplemented has a beneficial impact on the growth of these muscle tissues.
\end{abstract}

Key words:Broilers, Tulsi, Breast, Thigh, Leg

\section{Introduction}

Feed is a major component, affecting net return from the poultry business, because $80 \%$ of the total expenditure in terms of cash is spent on feed purchase (Khan et al., 2010). To ensure more net return and to minimize high expenditure on feed are the main challenges, for which many research strategies have been practiced such as introducing feed supplements and feed additives (Khan et al., 2009). In the past the major growth promoters were antibiotics. However the current research is looking for natural alternative to antibiotics because of their residue and subsequent resistance to bacteria. One of the major challenges faced by the poultry industry in the developing world is about improving efficiency of production. To meet this challenge and maintain the efficiency of feed utilization, series of attempts have been made by researchers. These include incorporation of antimicrobials and other natural products, such as Yeasts and Aloe vera to animals and poultry feeds. It is well documented that antibiotics have a beneficial effect on animal growth, performance and health. However, increasing concerns regarding overuse of antibiotics has promoted extensive investigation into alternatives to use the sub-therapeutic antibiotics in production yeast (Gao et al., 2008).Aloe vera and yeast are the two medicinal plants found in tropical regions of India and are commonly incorporated in most of the poultry herbal medicines like liver tonics, anti-stress, antioxidants, antitoxic and growth promoting preparations. Apart from these benefits, these two herbs are used for various functions like antibacterial, antiseptic, anti inflammatory, nematocidal and immunomodulatory properties. Besides, usage of these herbs for medicinal preparations, it can also be included in the poultry diet as feed additive to utilize their benefits to the maximum extent. Hence, this research work was designed in broilers by including different levels of Aloe vera, Yeast and their combinations to study the carcass characteristics and growth of muscles in broilers.

\section{Materials And Methods}

A total of $72 \mathrm{DOC}$ of same hatch were randomly distributed into four groups i.e. $\mathrm{T}_{1}$ (Control), treatment $T_{2}, T_{3}$ and $T_{4}$ with six sub groups comprising of three birds in each. Broilers in $T_{1}$ were fed diet as per (NRC, 1994) standard (CP 22 and ME 2900) but broilers in $T_{2}, T_{3}$ and $T_{4}$ were fed standard ration supplemented with $0.50 \%$ (Yeast), $0.50 \%$ (Aloe vera), and $0.50 \%$ Yeast $+0.50 \%$ Aloe vera powder. All broilers were offered feed and water ad libitum throughout the experimental period. They were housed in metal type battery cages in small animal laboratory of S.S. and AH Dairying, SHIATS Allahabad. A bulb of 15 watt was left on in each cage. Initial weight of each chick was recorded on arrival and then weekly.

Table 1 Ingredient and nutrient composition of experimental diet (\%DM)

Ingredients $(\%) \quad$ Broiler starter $(0-21$ days $)$

42 days)

Maize

Ground nut cake

Fish meal

Premix*

Salt
60.00

23.11

12.60

2.50

0.30
Broiler finisher (22 -

63.00

18.00

14.60

2.50

0.30 
Effect of Dietary Aloe vera and Yeast powder on muscle growth of broiler chicks

Methionine

lysine

Di-calcium phosphate

Total

Moisture (\%)

Crude Protein (\%)

Total Ash (\%)

$\mathrm{CP}$

$\mathrm{ME}(\mathrm{Kcal} / \mathrm{Kg})$

Calcium (\%)

Available phosphate(\%)

Methionine(\%)

Lysine $(\%)$
0.10

0.10

1.20

100

Calculated Chemical analysis

6.29

23.29

8.02

22.00

2900

0.69

0.74

0.33

1.19
0.01

0.01

1.20

100

6.22

21.28

9.34

19.00

3000

0.52

0.69

0.31

1.08

*Premix (2.5\%) Provided the following (Per Kg of complete diets).Vit A. 367500 IU,133500 IU Vit. D3, $1920 \mathrm{mg}$ Vit.E, 84.42 Vit.K3, $50 \mathrm{mg}$ Vit.B1, $150 \mathrm{mg}$ Vit.B2, $500 \mathrm{mg}$ Vit.B3, $177.5 \mathrm{mg}$ Vit.B6, $0.8 \mathrm{mg}$ Vit.B12, $600 \mathrm{mg}$ Vit. PP, $24.5 \mathrm{mg}$ folic acid, $27 \mathrm{mg}$ biotin, $5767.5 \mathrm{mg}$ choline, $2667 \mathrm{mg} \mathrm{Fe,} 333.75 \mathrm{mg} \mathrm{Cu}$, 3334.06 mg Mn , $203 \mathrm{mg}$ Co , $2334.38 \mathrm{mg} \mathrm{Zn,} \mathrm{100.75} \mathrm{mg} \mathrm{Ca,} 10 \mathrm{mg} \mathrm{Se,} \mathrm{65446.46} \mathrm{mg} \mathrm{Ph,} 36667.5 \mathrm{mg}$ DLMithionine, 200.02mg, Ethoxyquin,50mg Flavo phospholipol, 30g Fish meal, 1800g wheat bran.

Green Aloe vera leaves were dried for three to four days initially and then in oven at $60^{\circ} \mathrm{C}$ up to moisture content level below $10 \%$. Then the leaves were crushed manually to make it fine. It was passed through fine meshed wire sieve to obtain uniform powder. Then it was mixed with standard feed mixture according to the ratio mentioned. Chicks were provided 0.8 sq.ft/bird space. Cages, feeders, waterers, and other equipments were properly cleaned disinfected and sterilized before use. The waterers were disinfected with $0.02 \% \mathrm{KMnO} 4$ solution every day. The average live body weight, body weight gain, feed intake, mortality percent and feed conversion ratio were measured on weekly basis. At the end of experiment, randomly selected nine birds from each group were killed humanely. Internal organs were separated including abdominal fats and neck in such a way that only the solid muscular portion remained. Breast, right thigh and right leg of each bird were weighed on a wing balance on fresh basis. The Data obtained were subjected to statistical analysis using ANOVA. In case of significance difference Duncan Multiple Range Test was applied.

\section{Results And Discussion}

Data on feed intake, water intake and weight of breast, thigh and leg are shown in Table 2. Mean feed and water intake was non significant in control and treated groups. The weight of breast, thigh and leg were significantly heavier $(\mathrm{P}<0.05)$ in treatments $\mathrm{T}_{4}(0.50 \%$ Yeast $+0.50 \%$ Aloe vera $)$ compared to control. The results of this experiment show clearly a positive effect of $0.50 \%$ Yeast $+0.50 \%$ Aloe vera powder feed supplemented on the weight of the breast, leg and thigh of broiler chicks. Mean feed intake and water consumption were non significant in control and treated groups. It is interesting to note that the beneficial effect of this plant is not due to better feed efficiency, since feed intake was non significant between control and treatmentgroups. Similarly, thenon significant water intake between control and treatedgroups indicate that the higher weight of breast, leg andthigh are not due to better water consumption andconsequently the water accumulation in the organs inquestion in the treated groups. In this experiment, weobtained better weight in terms of breast, leg and thighin treatment group having treated $0.50 \%$ Yeast $+0.50 \%$ Aloe vera powder feed supplemented.

Table 2: Mean feed consumption, water intake, breast weight, thigh weight and leg weight of broilers.

\begin{tabular}{|c|c|c|c|c|}
\hline \multirow[t]{2}{*}{ Parameters Groups } & \multicolumn{4}{|c|}{ Treatments } \\
\hline & $\mathrm{T}_{1}$ & $\mathrm{~T}_{2}$ & $\mathrm{~T}_{3}$ & $\mathrm{~T}_{4}$ \\
\hline Feed intake $(\mathrm{g})$ & $3265 \pm 49$ & $32571 \pm 50$ & $3246 \pm 105$ & $3208 \pm 125$ \\
\hline Water intake (ml) & $5895 \pm 300$ & $5881 \pm 133$ & $5879 \pm 189$ & $5893 \pm 267$ \\
\hline Breast weight (g) & $263.77 \pm 13.44^{b}$ & $265.45 \pm 21.33^{b}$ & $270.98 \pm 19.72^{\mathrm{b}}$ & $305.2 \pm 12.65^{\mathrm{a}}$ \\
\hline Thigh weight (g) & $59.76 \pm 3.4^{\mathrm{b}}$ & $61.11 \pm 3.3^{\mathrm{b}}$ & $63.12 \pm 2.9^{\mathrm{b}}$ & $72.55 \pm 3.00^{\mathrm{a}}$ \\
\hline Leg weight $(\mathrm{g})$ & $64.12 \pm 5.76^{\mathrm{b}}$ & $65.34 \pm 6.36^{b}$ & $68.44 \pm 4.4^{\mathrm{b}}$ & $76.55 \pm 3.77^{\mathrm{a}}$ \\
\hline
\end{tabular}


Values (Mean \pm SE) with different superscripts in a row differ significantly $(\mathbf{P}<0.05)$; $\mathbf{T}_{1}=$ Control; $\mathbf{T}_{2}=$ $0.50 \%$ Yeast (Saccharomyces Cerevisiae) powder; $\mathbf{T}_{3}=\mathbf{0 . 5 0 \%}$ Aloe vera (Aloe barbadensis) powder; $\mathbf{T}_{\mathbf{4}}=\mathbf{0 . 5 0 \%}$ Yeast $+\mathbf{0 . 5 0 \%}$ Aloe vera powder in basal diet.

Our findings are similar to Al-Homidan and Fahmy, (2007)Yeast, which is known as "Baker Yeast" is rich in crude protein (40-45\%) and vitamin B complex. Yeast extracts have been widely reported as successful growth promoter in poultry industry. The present increase in muscle weight may be due to the mode of action of dry yeast in poultry includes and maintaining normal intestinal microflora by competitive exclusion and antagonism hence altering metabolism by increasing digestive enzyme activity and decreasing bacterial enzyme activity and ammonia production hence the improving digestion reported byLutfulKabir (2009). After many research studies on animal and human being, Sinurat, et al.(2002) reported that Aloe verabioactives as feed additive: the effect of different forms and levels of bioactives on performances of broilers. Therefore, there is likelihood thatimproved metabolism has beneficial impact on weightgain of the studied muscles. Comparative higher weightof breast, leg and thigh in treatmentis attributed to the nutritive effect ofSaccharomyces Cerevisiae and Aloe barbadensis. Gomez et al. (1998) concluded that theimprovement in live body weight in broilers may bedue to antibacterial related to flavonoids in Aloe barbadensis that led to maintaining normal intestine microflora by competitive exclusion and antagonism, alteringmetabolism and increased liver and muscle glycogencontents.In conclusion it can be said that $0.50 \%$ Yeast $+0.50 \%$ Aloe vera powder feed supplemented of drinking water produced positiveresults in broiler chicks. It may also decrease the marketage of broilers and reduce their rearing cost.

\section{Refrences}

[1]. Al-Homidan, A and M. O. Fahmy 2007. The effect of dried yeast (Saccharomyces Cerevisiae) supplementation on growth performance, carcass chemical analysis, immunity, ileum villi heights and bacterial count of broiler chickens. Egypt Poul. Sci., 27 (111):613-623.

[2]. Duncan, D.B. 1955. Multiple range and multiple F tests. Biometrics. 11:1-42.

[3]. Gao, J.,H.J. Zhang, S. H. Yu , S.G. Wu,I. Yoon, J. Qurgley, Y. P. Gao and G. H. Qi 2008. Effects of yeast culture in broiler diets on performance and immune-modulatory functions. Poul. Sci., 87:1377-1384.

[4]. Gomez, M.P., Geetha, B., and Aasker, G. 1998.Antidiabetic effects of fenugreek extract(Trigonellafoenum-graecum L.) on domesticanimals with special reference to carbohydratemetabolism. Journal of Ecotoxicology andEnvironmental Monitoring, 8: 103108.

[5]. Khan, F.U., Durrani, F.R., Sultan, A., Khan, R.U. andNaz, S. 2009. Effect of fenugreek (Trigonellafoenumgraecum) seed extract on visceral organsof broiler chicks. ARPN.Journal of Agriculturaland Biological Sciences, 4: 58-61.

[6]. Khan, R.U., Durrani, F.R., Chand, N. and Anwar, H.2010. Influence of feed supplementation withCannabis sativa on quality of broilers carcass.Pakistan Veterinary Journal, 30: 34-38.

[7]. LutfulKabir, S.M (2009). The role of probiotics in the poult industry. Int. J. Mol. Sci., 10: 3531-3546.

[8]. National Research Council, (NRC). 1994. Nutrient Requirements of Poultry 9th Ed. National Academy Press. Washington, DC. ofAlletchs 10th Annual Symposium .Nottingham University Press. Nottingham, UK.

[9]. Sinurat, et al., 2002. Responses of broilers to Aloe verabioactives as feed additive: the effect of different forms and levels of bioactives on performances of broilers. J. ILmu. Ternak.dan.Veteriner., 7: 69-75. methods.8th edn, Iowa State University Press/Ames, Iowa-50010. 